\title{
SCREENING OF VEGETABLES FOR PHYTOEXTRACTION OF HEAVY METALS
}

\author{
Baby Sharma Kafle \\ Amrit Campus, Tribhuvan University, Kathmandu, Nepal
}

\begin{abstract}
To understand the phytoextraction of heavy metals from contaminated soil, eighteen seasonal vegetable crops were investigated. The soil was artificially contaminated each with $300 \mathrm{mg} \mathrm{kg} \mathrm{kg}^{-1}$ $\mathrm{CuCl}_{2}, 500 \mathrm{mg} \mathrm{kg}{ }^{-1} \mathrm{~Pb}\left(\mathrm{NO}_{3}\right)_{2}, 800 \mathrm{mg} \mathrm{kg}^{-1} \mathrm{ZnCl}_{2}$ or their mixed metal $\left(1600 \mathrm{mg} \mathrm{kg}^{-1}\right)$. Lowest copper $(\mathrm{Cu})$ accumulation was recorded in Brassica juncea and highest in Vicia faba, while lowest lead $(\mathrm{Pb})$ accumulation in Solanum tuberosum, and highest in Allium fistulossum; and lowest zinc (Zn) accumulation in both Allium fistulossum and Solanum tuberosum, and highest was in Vicia faba from the single metal contamination. Similarly, lowest $\mathrm{Cu}, \mathrm{Pb}$ and $\mathrm{Zn}$ was recorded in Brassica juncea, Brassica caulorapa and Allium fistulossum, respectively; and highest accumulation of $\mathrm{Cu}$ and $\mathrm{Pb}$ was in Spinacea oleracea and $\mathrm{Zn}$ in Spinacea oleracea from their mixed metal treatments.
\end{abstract}

Key words: Phytoextraction, vegetables, heavy metals.

\section{INTRODUCTION}

The continuous increase of non-degradable heavy metals, such as cadmium $(\mathrm{Cd})$, arsenic (As), mercury $(\mathrm{Hg})$, silver $(\mathrm{Ag})$ and lead $(\mathrm{Pb})$ which are emitted via anthropogenic activities in the environment, have no biological function as nutrients (Nies 1999). Heavy metals from the industrial emissions, household waste, sewage sludge, pesticides and fertilizers are major global problems as ultimately contribute to the deposition on soil of urban and sub urban areas (Lagerwerff and Spect 1970, Goyer 1997). Heavy metal contaminated soils reduce plant species richness and increase biologically inactive land via destroying soil quality by the influences on the breakdown of organic matter with the negative activity of microorganisms and earthworms (McLean 1975).
With regard to uptake of metals and their accumulation, plants are excluders, indicators/ or accumulators and hyperaccumulator. The genus Allyssum and Thlaspi, (both species belonging to family Brassicaceae) which have effective capability in reducing heavy metal from the contaminated soil by accumulating high load of $\mathrm{Zn}$, $\mathrm{Ni}, \mathrm{Cd}$ and $\mathrm{Pb}$ in their body (Baker 1981, Baker et al. 1994, Chaney et al. 1997). Hyper-accumulator has generally slow growth with production of low biomass. Most plant species tend to exhibit higher heavy metal levels in the root and shoots in responses to increasing levels of heavy metals in the soil (Hutchinson and Whitby 1974, Pietz et al. 1978). Plants which develop tolerances mechanisms against phytotoxicity, constitute a risk factor for human health via food chain, create dangerous situation through direct consumption of 
edible plants or indirectly from animals coming from the heavy metal contaminated fields (Lantzy and Mackenzie 1979, Angelone and Bini 1992).

Copper and zinc, are the essential micronutrients, especially in the production of blood haemoglobin in human, but in high doses, cause anaemia, liver, kidney damage, stomach/intestinal irritation, sexual immaturity, grey hair, dehydration, damage of mucous membrane, (WHO 1996, VCI 2011). Lead (Pb) may cause various problems in human body part like gastrointestinal tract, kidneys, central nervous system and brain. Memory loss, nausea, insomnia, anorexia, damage in the red blood cells, and weakness of the joints are some of the symptoms of $\mathrm{Pb}$ toxicity in human. Lead influences the genetic structure and evolution of exposed plant and animal populations (Johnson 1998, Baldwin and Marshall 1999, NSC 2009).

Various bioremedial works have been conducted to reduce heavy metal contamination from contaminated soils. Heavy metal tolerance in cowpea (leguminous) plants was increased by dual inoculation of an arbuscular mycorrhizal fungi and nitrogen-fixer Rhizobium bacterium (Saleh and Saleh 2006). Indian mustard (Brassica juncea) was an effective plants for phytoextracting $\mathrm{Zn}$ after the application of the synthetic chelates EDTA (ethylenediamine tetraacetic acid) when compared to the oat (Avena sativa) and barley (Hordeum vulgare) grown from the $\mathrm{Zn}$ contaminated soil (Ebbs and Kocchian 1998, Nowack et al. 2006). But EDTA has been found associated with high toxicity and persistence in the environment (Tandy et al. 2004, Evangelou 2007). Sorghum spp can be used in remediation process, because their fibrous root show the efficiency in accumulation of heavy metals (Jadia and Fulekar 2008). Further, the use of phytoextraction are simple, more economically viable and environment friendly (Garbisu and Alkorta 2001). A variety of plant species like Brassica juncea, Hibiscus cannabinus,
Abelmoschus esculentum, Beta vulgaris L., Oryza sativa L., Arabidopsis halleri were studied for extracting Cd from contaminated soil (Yanai et al. 2004, Ishikawa et al. 2006, Murakami et al. 2007).

Information about heavy metal accumulation among vegetables is important to understand the best accumulator. On this basis, planning can be made for cultivation of particular vegetable crops in heavy metal contaminated soil. The main objective of this study is to identify the suitable vegetable species for phytoextraction of heavy metals from heavy metal contaminated soil.

\section{MATERIALS AND METHODS}

Vegetables are valuable being the rich sources of minerals ( $\mathrm{Ca}, \mathrm{Mg}, \mathrm{Fe}, \mathrm{P}, \mathrm{K}, \mathrm{S}$ ), amino acids, vitamins [Vit. A (antioxidant) Vit.C (ascorbic acid), Vit. E (tocopherol) and Vit. K (antihaemorohagic factor)] and dietary fibers.

Some common vegetables which are cultivated in Kathmandu valley are selected for the present study. Seeds of vegetables such as Beta vulgaris L. (Beet root) Chukandar, Beta vulgaris var. cicla (Swiss Chard) Foliage beet, Brassica juncea L. (Broad leaf mustard) Rayo sag, Brassica caulorapa L. (Kohlrabi) Gyathgobi, Brassica rapa L. (Turnip) Gantemula, Brassica rapa L. var. purple top globe (Turnip) Salgam, Lepidium sativum L. (Pepper Cress) Chamssor, Raphanus sativus L. (Radish), Puthane Rato, Raphanus sativus L. (Radish), Puthane Seto mula, Coriandrum sativum L. (Coriander) Dhaniya, Spinacia oleracea L. (spinach) Patane palungo, Spinacia oleracea L. inermis (round seeded spinach) Deshi palungo, Spinacia oleracea L. (Prickly seeded spinach) Gobre, Trigonella foenumgraecum L. (Fenugreek) Methi and Vicia faba L. (Broad bean) Bakula were collected from reliable seed store (Annapurna Beez Bhandar, Ason). Some bulbets such as Allium sativum L (Garlic) Lahsun, Allium fistulosum L. (Cibol or Welsh onion) Chyapee, and tubers Solanum 
tuberosum L. (Potato) Aalu, were purchased from local market of Kathmandu.

The seeds/ bulbets / tuber of the vegetables were grown in polythene bags containing $3.5 \mathrm{~kg}$ of sandy loam soil which were artificially contaminated each with $300 \mathrm{mg} \mathrm{kg}^{-1} \mathrm{CuCl}_{2} / 500$ $\mathrm{mg} \mathrm{kg}^{-1} \mathrm{~Pb}\left(\mathrm{NO}_{3}\right)_{2} / 800 \mathrm{mg} \mathrm{kg}^{-1} \mathrm{ZnCl}_{2} /$ or with their mixed concentration $\left(=1600 \mathrm{mg} \mathrm{kg}^{-1}\right.$ soil). Triplicate bags of each vegetable per treatment for experiment were arranged in randomized block design.

The cultivated vegetables were harvested after 5 weeks. The harvested vegetables were cleaned thoroughly with tap water for the removal of outer contamination (soil particles and aerial) and were finally washed with de-ionized water. The vegetables were air dried for two to three days and finally oven dried at 60 to $70^{\circ} \mathrm{C}$ up to constant dry weight. The representative samples were made powder by using Mortar and pestle. Analysis of the representative samples ( $1 \mathrm{~g}$ dry weight) of each vegetables were used for the wet digestion process by using concentrated $\mathrm{HNO}_{3}$ (Chettri et al. 1997). Metal concentration of $\mathrm{Cu}, \mathrm{Pb}$ and $\mathrm{Zn}$ from triplicate samples were analyzed with the conduction of Atomic Absorption Spectrometry (AAS) using $324.7 \mathrm{~nm}$ for $\mathrm{Cu}, 283.3 \mathrm{~nm}$ for $\mathrm{Pb}$ and $213.9 \mathrm{~nm}$ for $\mathrm{Zn}$ (Welz, 1985). Two plant materials of NBS standards (National Bureau of Standards, USA) with Nos. 1573 (Tomato leaves) and 1575 (Pine needles) were also analyzed, following the same procedure and the metal recoveries ranged from 94 to 99 percent. Sandy loam soil $3.5 \mathrm{~kg}$ per bag were artificially contaminated each with $300 \mathrm{mg} \mathrm{kg}^{-1} \mathrm{CuCl}_{2} / 500$ $\mathrm{mg} \mathrm{kg}{ }^{-1} \mathrm{~Pb}\left(\mathrm{NO}_{3}\right)_{2} / 800 \mathrm{mg} \mathrm{kg}{ }^{-1} \mathrm{ZnCl}_{2} /$ or with their mixed concentration $\left(=1600 \mathrm{mg} \mathrm{kg}^{-1}\right.$ soil).

\section{RESULTS}

Among the tested vegetable crops for phytoextraction, copper accumulation $<25 \mathrm{mg} \mathrm{kg}^{-1}$ from $300 \mathrm{mg} \mathrm{CuCl}_{2} \mathrm{~kg}^{-1}$ soil treatments, were observed in A. sativum, L. sativum and white $R$. sativus but low $\mathrm{Cu}$ accumulation (20-22 $\mathrm{mg} \mathrm{kg}^{-1}$ DW) were observed in $B$. juncea and $B$. caulorapa. Moderate $\mathrm{Cu}$ accumulation (ranging from 25 to $50 \mathrm{mg} \mathrm{kg}^{-1}$ ) was recorded in $T$. foenumgraecum, B. rapa and $C$. sativum. High $\mathrm{Cu}$ accumulation (50 to $100 \mathrm{mg} \mathrm{kg}^{-1}$ ) was observed in A. fistulossum, S. (Deshi), S. oleracea (Patane), S. oleracea (Gobre) and Beta vulgaris var. cicla (Swiss chard). Among studied vegetables, V. faba accumulated high concentration of $\mathrm{Cu}(432.5 \mathrm{mg}$ $\mathrm{kg}^{-1}$ ). Solanum tuberosum, Beta vulgaris (beet root), $R$. sativus (red radish) and B. rapa var. purple top globe (salgam) could not germinate on soil with $300 \mathrm{mg} \mathrm{CuCl}_{2} \mathrm{~kg}^{-1}$ contamination (Fig. 1). In Figs. 1-4, Spinacia oleracea Deshi is indicated as inermis, S. oleracea Patanae as Shankhamul and S. oleracea Gobre as Thimi.

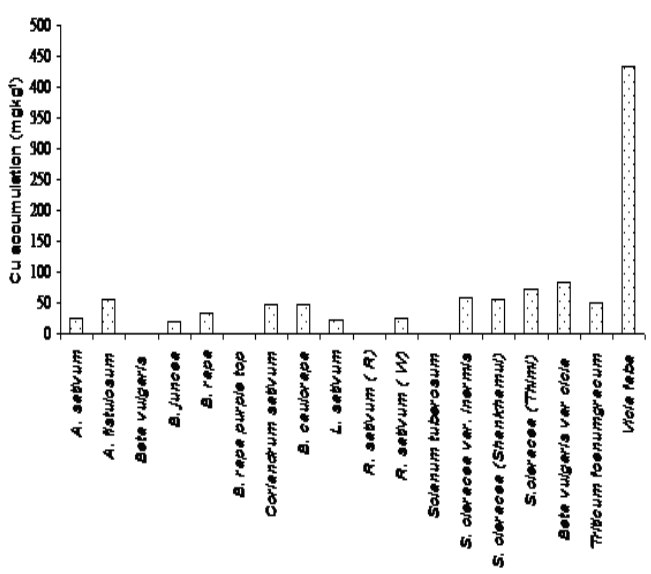

Fig. 1. Phytoextraction of copper by vegetable crops grown on soil with $\mathrm{CuCl}_{2}$ treatment.

Among the vegetable crops for phytoextraction test, lead accumulation $<50 \mathrm{mg} \mathrm{kg} \mathrm{kg}^{-1}$ from $500 \mathrm{mg}$ $\mathrm{Pb}\left(\mathrm{NO}_{3}\right)_{2} \mathrm{~kg}^{-1}$ soil treatments was observed in Beta vulgaris (beet root), B. juncea, R. sativus (red), B. caulorapa, $R$. sativus (W) and $S$. tuberosum. Lowest $\mathrm{Pb}$ accumulation was observed in $S$. tuberosum. Moderate accumulation of $\mathrm{Pb}(50$ to $100 \mathrm{mg} \mathrm{kg}^{-1}$ ) was recorded in A. sativum, $L$. 
sativum, S. oleracea (Deshi), S. oleracea (Patane) and Beta vulgaris var. cicla (Swiss chard). Highest accumulation of $\mathrm{Pb}\left(512.5 \mathrm{mg} \mathrm{kg}^{-1}\right)$ was noticed in A. fistulosum followed by C. sativum, V. faba, B. rapa var. purple top globe and $S$. oleracea (Gobre). Trigonella foenumgraecum could not germinate in $500 \mathrm{mg} \mathrm{Pb}\left(\mathrm{NO}_{3}\right)_{2} \mathrm{~kg}^{-1}$ contaminated soil (Fig. 2).

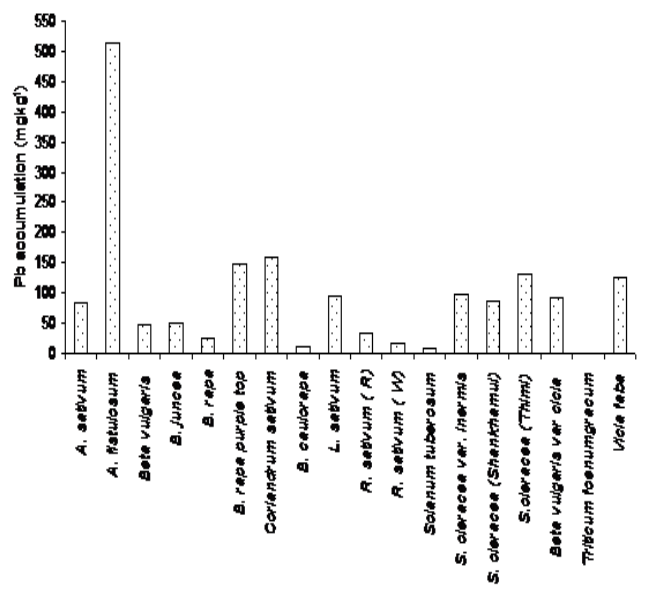

Fig. 2. Phytoextraction of lead by vegetable crops grown on soil with $\mathrm{Pb}\left(\mathrm{No}_{2}\right)_{3}$ treatment

Among the tested vegetable crops for phytoextraction of Zinc from $800 \mathrm{mg} \mathrm{ZnCl}_{2} \mathrm{mg}$ $\mathrm{kg}^{-1}, \mathrm{Zn}$ accumulation was highest in $V$. faba (broad bean) (202 $\mathrm{mg} \mathrm{kg}^{-1}$ ) followed by L. sativum. Low $\mathrm{Zn}\left(<100 \mathrm{mg} \mathrm{kg}^{-1}\right)$ was accumulated in $A$. sativum, A. fistulosum, $B$. caulorapa, $T$. foenumgraecum, Solanum tuberosum, $R$. sativus (both red and white radish), B. rapa var. purple top globe, S. oleracea (Deshi), S. oleracea (Gobre). Moderate $\mathrm{Zn}$ accumulation, ranging from 100 to $200 \mathrm{mg} \mathrm{kg}^{-1}$ was recorded in $B$. juncea, S. oleracea (patane), Beta vulgaris var. cicla. Coriandrum sativum could not germinate in $800 \mathrm{mg} \mathrm{ZnCl} \mathrm{kg}^{-1}$ contaminated soil (Fig. 3).

Among the tested vegetable crops for phytoextraction of $\mathrm{Cu}, \mathrm{Pb}$ and $\mathrm{Zn}$, from their (1600 $\mathrm{mg}$ ) mixed metal $\mathrm{kg}^{-1}$ soil treatments, $\mathrm{Cu}$ accumulation in B. juncea, C. sativum, B. rapa (both varieties), $S$. tuberosum and $T$. foenumgraecum have less than $15 \mathrm{mg} \mathrm{kg}^{-1}$. Allium fistulosum, V. faba, S. oleracea (Patane), Beta vulgaris var. cicla and $S$. oleracea (Deshi) showed moderate $\mathrm{Cu}$ accumulation $\left(15-29.5 \mathrm{mg} \mathrm{kg}{ }^{-1}\right.$ $\mathrm{DW})$. Accumulation of $\mathrm{Pb}$ in most vegetables was $<10 \mathrm{mg} \mathrm{kg}^{-1}$ from the mixed metal treated soil and were within the range of 5.83 ( $S$. tuberosum) to $30.5 \mathrm{mg} \mathrm{kg}^{-1}$ ( . oleracea Deshi).

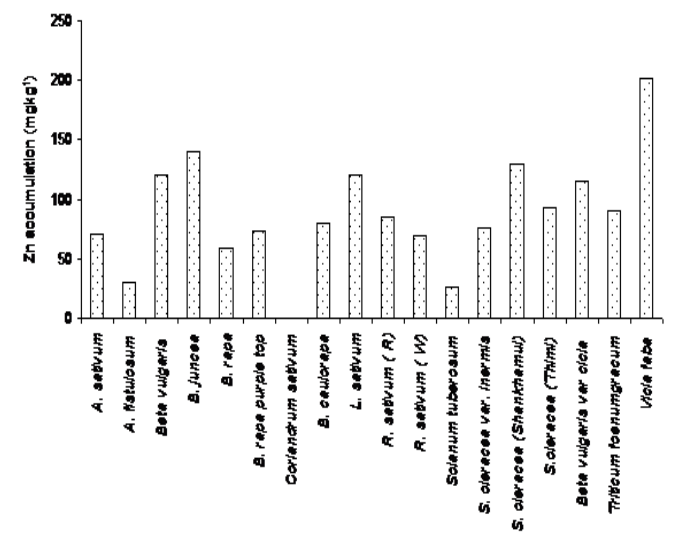

Fig. 3. Phytoextraction of zinc by vegetable crops grown on soil with $\mathrm{ZnCl}_{2}$ treatment

Zinc accumulation ranged from 100-200 mg $\mathrm{kg}^{-1}$ in Beta vulgaris (beetroot), L. sativum, T. foenumgraecum, $R$. sativus (red), $S$. oleracea (Gobre) and Beta vulgaris var. cicla. More than $200 \mathrm{mg} \mathrm{kg}^{-1} \mathrm{Zn}$ accumulation was noticed in $V$. faba, B. caulorapa, B. rapa var. purple top globe, S. oleracea (Deshi) and S. oleracea (Patane). Among these vegetables, S. oleracea (Patane) accumulated highest amount of $\mathrm{Zn}\left(335.5 \mathrm{mg} \mathrm{kg}{ }^{-1}\right)$. Out of red and white varieties of radish, the former accumulated more $\mathrm{Cu}, \mathrm{Pb}$ and $\mathrm{Zn}$ than the later. Similarly, among the three varieties of $S$. oleracea, $\mathrm{Cu}$ and $\mathrm{Zn}$ accumulation was low in Gobre, but $\mathrm{Pb}$ accumulation was more or less similar in all three varieties. Zinc accumulation was higher in S. oleracea (Patane) than in others two varieties (Fig. 4). 


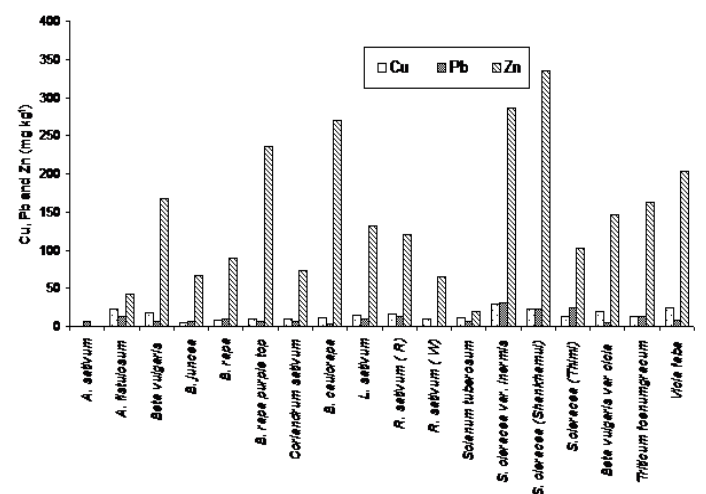

Fig. 4. Phytoextraction of $\mathrm{Cu}, \mathrm{Pb}$ and $\mathrm{Zn}$ by vegetables grown on soil with mixed metals $\left(\begin{array}{llll}\mathrm{CuCl}_{2} & +\mathrm{Pb} & \left(\mathrm{No}_{2}\right)_{3} & +\mathrm{ZnCl}_{2}\end{array}\right)$ treatments.

\section{DISCUSSION}

The accumulation of $\mathrm{Cu}$ and $\mathrm{Zn}$ in $V$. faba among vegetables tested for phytoextraction indicated that the responses of plants to the exposure to heavy metals are complicated due to variable tolerance as well as multivariable relationships between the concentration of soil metals and plants metals (Kabata-Pendais et al. 1993). High accumulation of $\mathrm{Cu}$ in $V$. faba is mainly due to presence of high proteins and bitter alkaloid compounds (Daniels et al. 1997, Jain 2007). Presence of alkaloid like lignin, phenols, etc along with $-\mathrm{NH}_{2}$ group forms complex with accumulated $\mathrm{Cu}$ and this enhances $\mathrm{Cu}$ accumulation. In the present study potato could not grow in $\mathrm{CuCl}_{2}$ contaminated soil but showed highly reduced accumulation of $\mathrm{Pb}$ and $\mathrm{Zn}$ from both single and their mixed metal treatments. Reduced uptake of heavy metals is one of the plant adaptation strategies to avoid metal toxicity (Baker and Walker 1990). Out of these tested vegetable crops, reduced uptake mechanism has been identified in potato tuber, which is possibly due to high starch content. Highest accumulation of $\mathrm{Pb}$ was observed in A. fistulosum. Possible reason for this may be due to presence of organosulphur, like cystein di- sulphide, methionine, glutamine which form complex with $\mathrm{Pb}$ because of being a border line metal (Streit and Stumm 1993, Kuiper 2005). Low accumulation of $\mathrm{Pb}$ less than lower range of critical tissue concentration of $20 \mathrm{mg} \mathrm{kg}^{-1} \mathrm{DW}$ as suggested by Kabata-Pendais et al. (1993) was observed in B. caulorapa, $R$. sativus (white) and $S$. tuberosum. High accumulation of $\mathrm{Zn}$ in $B$. juncea supports the finding of Kumar et al. (1995) and Salt et al. (1995). They suggested B. juncea, to be more effective than Thlaspi caerulescens in phytoextracting $\mathrm{Zn}$, as it removed 4 folds more $\mathrm{Zn}$ than T. caerulescens (Ebbs and Kochain 1998). This was due to the fact that $B$. juncea produced 10 times more biomass than $T$. caerulescens.

In the mixed metal condition, $S$. oleracea (Patane and Deshi), B. caulorapa showed high $\mathrm{Zn}$ accumulation which is in contrast to $\mathrm{Zn}$ accumulation from the single metal treatment. High accumulation of $\mathrm{Pb}$ and $\mathrm{Cu}$ was observed in $S$. oleracea (inermis which is also indicated as Deshi) from mixed metal treatment. High uptake of $\mathrm{Zn}, \mathrm{Pb}$ or $\mathrm{Cu}$ from the mixed metal treatments in the plants may be due to competitive uptake among the supplied cations. This result is further justified from the monitoring experiment where the $\mathrm{Zn}$ accumulation in S. oleracea (in all species) is high and have tendency of hyperaccumulation (Sharma and Chettri 2005).

From single and mixed metal treatments, it is observed that heavy metal accumulation in vegetables is not only dependent on the concentration of supplied cations in the soil but also on the availability of other metal species at rhizospheric soil environment.

Present study identified some vegetables to be very sensitive, some as good accumulator/ or some as moderate or some as low accumulator of heavy metals. Vegetables like potato, beet root, turnip and radish could not germinate and grow in $\mathrm{Cu}$ contaminated soil. Fenugreek (T. foenumgraecum) and coriander ( $C$. sativum) could not germinate and grow in $\mathrm{Pb}$ and $\mathrm{Zn}$ contaminated soil, 
respectively. Similarly, A. fistulosum could not germinate in mixed metal contaminated soil.

Best $\mathrm{Cu}$ accumulator are $V$. faba followed by Beta vulgaris var. cicla, S. oeracea (Thimi), A fistulosum when grown on $\mathrm{Cu}$ contaminated soil. A fistulosum followed by Brassica rapa purple top, C. sativum, S. olearacea (Thimi), V. faba are best $\mathrm{Pb}$ accumulator. $V$. faba $>S$. olearaca (Shankhamul), Brassica juncea, L. sativum, Beta vulgaris var cicla are the best $\mathrm{Zn}$ accumulator.

$T$. foenumgraecum, B. rapa and $C$. sativum are the moderate $\mathrm{Cu}$ accumulator. A sativum, $L$ sativum, S oleracea (deshi) S. olearacea (patne) and Beta vulgaris var. cicla are moderate $\mathrm{Pb}$ accumulator. B.juncea, S. oleracea (patne), B. vulgaris var cicla are the moderate $\mathrm{Zn}$ accumulator.

B. juncea is low $\mathrm{Cu}$ accumulator. Solanum tubersoum is low accumulator of both $\mathrm{Pb}$ and $\mathrm{Zn}$ from single heavy metal treatment while $B$. juncea, B. caulorapa and $S$. tubersoum are the low accumulator of $\mathrm{Cu}, \mathrm{Pb}$ and $\mathrm{Zn}$, respectively, from mixed metal treated soil.

\section{ACKNOWLEDGEMENT}

The author is grateful to Prof. Dr. Mukesh K. Chettri for the valuable suggestion during the preparation of this manuscript, and also thankful to Amrit Campus for providing space for vegetable cultivation as well as research facilities.

\section{REFERENCES}

Angelone, M. and C. Bini. 1992. Trace elements concentrations in soils and plants of Western Europe. In: Biogeochemistry of Trace Metals. (ed.) Adriano, D.C. Boca Raton, Florida, Lewis Publishers, pp. 19-60.

Baker, A.J.M. 1981. Accumulators and excludersstrategies in the response of plants to heavy metals. J. Plant Nutr. 3:643-654.

Baker, A.J.M. and P.L. Walker. 1990. Ecophysiology of metal uptake by tolerant plants. In: Heavy Metal Tolerance in Plants: Evolutionary Aspects. (ed.) Shaw, A.J. CRC Press, Inc., Boca Raton, Florida, pp. 155-178.

Baker, A.J.M., R.D. Reeves and A.S.M. Hajar. 1994. Heavy metal accumulation and tolerance in British populations of the metallophyte, Thlaspi caerulescens J. and C. Presl (Brassicaseae). New Phytol. 127:61-88.

Baldwin, D.R. and W.J. Marshall. 1999. Heavy metal poisoning and its laboratory investigation. Annals of Clinical Biochemistry 36(3):267-300.

Chaney, R.L., M. Malik, Y.M. Li, S.L. Brown, E.P. Brewer, J.S. Angle and A.J.M. Baker. 1997. Phytoremediation of soil metals. Cur. Opi. Biotechnol. 8:279-284.

Chettri, M.K., T. Sawidis and S. Karataglis. 1997. Lichens as a tool for biogeochemical prospecting. Ecotox. Environ. Safety 38(1):322-335

Daniels, P., B. Kovacs, J. Prokish and Z. Gyori. 1997. Heavy metal dispersion detected in soils and plants along side roads in Hungary. Chemical Speciation and Bioavailability 9(3):83-93.

Ebbs, S.D. and L.V. Kochian. 1998. Phytoexcration of zinc by oat (Avena sativa), barley (Hordeum vulgare) and Indian mustard (Brassica juncea). Environ. Sci. and Technol. 32:802-806.

Evangelou, M.W.H., M. Ebel and A. Schaeffer. 2007. Chelate assisted phytoextraction of heavy metals from soil Effect, mechanism, toxicity, and fate of chelating agents. Chemosphere 68(6):989-1003.

Garbisu and I. Alkorta. 2001. Phytoextraction: a cost-effective plant-based technology for the removal of metals from the environment. Bioresource Technology 77(3):229-236.

ECOPRINT VOL 20, 2013 
Goyer, R.A .1997. Toxic and essential metal interactions. Annu. Rev. Biochem. 17:37-50.

Hutchinson, T.C. and L.M. Whitby. 1974. Heavy metal pollution in the Sudbury mining and smelting region of Canada. I. Soil and vegetation contamination by $\mathrm{Ni}, \mathrm{Cu}$ and other metal. Environ. Consrv. 1:123-132.

Ishikawa, S., N. Ae, M. Murakami and T. Wagatsuma. 2006. Is Brassica juncea a suitable plant for phytoremediation of cadmium in soils with moderately low cadmium contamination?_Possibility of using other plant species for Cd-phytoextraction. Soil Sci. Plant Nutr. 52:32-42.

Jadia, C.D. and M.H. Fulekar. 2008. Phytotoxicity and remediation of heavy metals by fibrous root grass (sorghum). Journal of Applied Biosciences 10(1):491-499.

Jain, V.K. 2007. Fundamentals of Plant Physiology. S. Chand and Company Ltd., New Delhi, 594 p.

Johnson, F.M. 1998. The genetic effects of environmental lead. Mutation Research 410:123-140.

Kabata-Pendias, A., M. Piotrowska and S. Dudka. 1993. Trace metals in legumes and monocotyledons and their suitability for the assessment of soil contamination. In: Plants as Biomonitors, Indicators for Heavy Metals in the Terrestrial Environment. (ed.) Markert, B. VCH-Publishers, Weinheim, New York, pp. 485-494.

Kuiper, K.M. 2005. S-allyl Mercaptocysteine Prodrugs and Methods Treatments. World Intellectual Property Organization (WIPO).

Kumar, P.B.A.N., V. Dushenkov, H. Motto and I. Raskin. 1995. Phytoextraction: the use of plants to remove heavy metals from soils. Environ. Sci. Technol. 29:1232-1238.
Lagerwerff, J.V. and A.W. Spect. 1970. Contamination of road side soil and vegetation with cadmium, nickel, lead and zinc. Environ. Sci. Tech. 4:583-586.

Lantzy, R.J. and F.T. MacKenzie. 1979. Atmospheric trace metals global cycles and assessment of man's impact. Geochimica of Cosmochimica Acta 43:511.

McLean, R.O. 1975. Zinc tolerance of Hormidium rivulare Kutz. Br. Phycol. J. 10:313.

Murakami, M., N. Ae and S. Ishikawa. 2007. Phytoextraction of cadmium by rice (Oryza sativa L.), Soybean (Glycine max L. Merr.), and maize (Zea mays L.). Environmental Pollution 145:96-103.

Nies, D.H. 1999. Microbial heavy metal resistance. Applied Microbial. Biotechnol. 51:730-750.

Nowack, B., R. Schulin and B.H. Robinson. 2006. Critical assessment of chelant-enhanced metal phytoextraction. Environmental Science and Technology 40(17):5225-5232.

NSC. 2009. Lead Poisoning, National Safety Council, USA.

Pietz, R.I., R.J. Vetter, D. Masarik and W.W. McFee. 1978. Zinc and Cadmium contents of agricultural soils and corn in northwestern Indiana. J. Environ. Qual. 7:381-385.

Tandy, S., K. Bossart, R. Mueller, J. Ritschel, L. Hauser, R. Schulin and B. Nowack. 2004. Extraction of heavy metals from soils using biodegradable chelating agents. Environmental Science and Technology 38:937-944.

Saleh, Al-G and M.I. Saleh. 2006. Increased heavy metal tolerance of cow pea plants by dual inocculation of an arbuscular mycorrhizal fungi and nitrogen fixer Rhizobium bacterium. African J. of Biotechnol. 16:133-142. 
Salt, D.E., M. Blaylock, P.B. Kumar, A.N. Dushenkov, V. Ensley, B.D. Chet and I. Raskin. 1995. Phytoremediation: a novel strategy for the removal of toxic metals from the environment using plants. Biotechnol. 13:468-474.

Sharma, B. and M.K. Chettri. 2005. Monitoring of heavy metals in vegetables and soil of agricultural fields of Kathmandu Valley. Ecoprint 12:1-9.

Streit, B. and W. Stumm. 1993. Chemical properties of metals and the process of bioaccumulation in terrestrial plants. In: Plants as Biomonitors Indicators for Heavy Metals in the Terrestrial Environment. (ed.) Markert, B.
VCH, Weinheim. New York. Basel, Cambridge, pp. 415-424.

VCI. 2011. Copper history/Future, Van Commodities Inc. http://trade metal futures. Com/copper history. html.

WHO. 1996. Trace Elements in Human Nutrition and Health. World Health Organization, Geneva.

Yanai, J., N. Mabuchi, N. Moritsuka, T. Kosaki. 2004. Changes in the distribution and forms of cadmium in the rhizosphere of Brassica juncea in Cd contaminated soils and implication for phytoremediation. Soil Sci. Plant Nutr. 50:423-430. 